18. Торічний О. В. Теорія і практика формування військово-спеціальної компетентності майбутніх офіцерів-прикордонників у процесі навчання. Хмельницький : Вид-во Національної академії ДПСУ, 2012. 535 с.

19. Ягупов В. В. Військова психологія : підручник. Київ : Тандем, 2004. 656 с.

УДК 159.9: 378-051

doi: 10.15330/psp.22.115-122

Галина Дубчак

\title{
АНАЛІЗ ОСОБИСТІСНИХ РЕСУРСІВ ПРОФЕСІЙНОЇ СТРЕСОСТІЙКОСТІ ФАХІВЦІВ СОЦІОНОМІЧНИХ ПРОФЕСІЙ
}

У статті обтрунтовано актуальність вивчення проблеми особистісних ресурсів професійної стресостійкості фахівиів соиіономічних професій. Розкрито зміст поняття «професійна стресостійкість». Представлено результати емпіричного дослідження особистісних ресурсів професійної стресостійкості студентів, щчо навчаються за соціономічними професіями та працюючих фахівців, визначено їх спільні та відмінні особливості. Виявлено, шуо для студентів закладів вищзї та середньої освіти характерним є низький та середній рівень психічної напруги, тоді як поведінка фахівиів характеризується більшою стресогенністю, високим рівнем ресурсності. Відзначено, що адаптаційні можливості людини і стійкість до стресогенних життєвих обставин обумовлені типом особистості, в якій провідну роль відіграють особистісні (сочіально-психологічні) ресурси.

Ключові слова: професійна підготовка, соціономічні професії, стрес, професійна стресостійкість, рівень психічної напруги.

The article substantiates the relevance of studying the problem of professional stress resistance of specialists of socionomic professions. The content of the concept "professional stressresistance» is explained. The paper presents the results of the empirical study of individual resources of professional stress resistanse students of socionomic profile and working professionals. There were determined the common and distinctive features of stress resistance of future and working specialists of various socionomic professions. It was found that for students of institutions of higher and secondary education characterized by low and average level of mental stress, while the behavior of specialists is characterized by greater stress-relatedness. Specialists have a high level of resource efficiency. It has been established that adaptive human capacities and resistance to stressful life circumstances are caused by the type of personality, in which the personal role (social-psychological) resources plays a leading role.

Keywords: professional training, socionomic professions, stress, professional stress resistance, level of mental tension.

\section{Постановка проблеми у загальному вигляді та їі зв'язок із важли-} вими науковими і практичними завданнями. Проблематика стресостійкості людини в різних професіях 3 давніх часів привертала увагу психологів різних напрямків. У дослідженнях багатьох авторів показано, що тривалий вплив стресу призводить до таких несприятливих впливів, як зниження загальної психічної стійкості організму, появи почуття незадоволення результатами своєї діяльності, тенденції до відмови від виконання завдань у ситуаціях підвищених вимог, невдач і поразок. Тому стресостійкість визнається одним із факторів, що впливає на ефективність професійної діяльності. 3 іншого боку, успішна профе- 
сійна діяльність є основою повноцінного переживання самореалізації, що впливає на задоволеність життям в цілому, на психологічну стійкість.

Особливого значення стійкість до стресу набуває для фахівців соціономічних професій, трудова діяльність яких $є$ одним 3 найбільш напружених в психологічному плані видів трудової активності. Тому успішність діяльності фахівців цього типу професій визначається не лише професійними знаннями i навичками, а й вміннями реалізовувати ці ресурси у своїй праці за рахунок розвитку відповідних професійно значущих якостей особистості.

Аналіз останніх досліджень і публікацій. На сьогоднішній день налічується достатня кількість наукових праць, присвячених питанням професійної підготовки майбутніх фахівців. Проте у працях, в яких досліджувались питання професійної підготовки фахівців соціономічних професій представлено лише окремі аспекти цієї проблеми. Зокрема, дослідження Н. С. Водоп'янової, О. М. Кокуна, К. О. Малишевої, О. Л. Марковець, Т. І. Ронгінської та інших, присвячено вивченню соціально-психологічних чинників професійної діяльності працівників допомагаючих професій, що провокують стресові стани, виникнення синдрому хронічної втоми та інші негативні симптоми. Однак, невивченими залишаються механізми та психологічні ресурси становлення професійної стресостійкості фахівців соціономічних професій. Недостатньо вивчено, також, вплив індивідуально-типологічних характеристик, особистісних властивостей фахівців з різним рівнем стресостійкості. Така тенденція свідчить про недостатню увагу, яку приділяють дослідники цій проблематиці і обумовлює наявність прогалини в підготовці спеціалістів соціально-орієнтованих професій.

Метою дослідження став порівняльний аналіз особистісних ресурсів професійної стресостійкості студентів та фахівців соціономічних професій, що допоможе зрозуміти механізми їі становлення у майбутніх фахівців соціономічних професій.

Виклад основного матеріалу. Професійну стресостійкість ми розглядаємо, грунтуючись на методології системного підходу, що дозволяє говорити про структуру психічної реальності - людина - професійне середовище, яка розглядається як динамічне ціле [2]. Виходячи 3 цього, професійну стресостійкість можна визначити як здатність людини протистояти негативному впливу стресових факторів професійної діяльності, зумовлену індивідуальним комплексом їі вроджених і набутих властивостей та процесів, які забезпечують оптимальне успішне досягнення мети трудової діяльності в складній емоціогенній ситуації [2]. Зі сказаного вище випливає, що професійна стресостійкість є окремим проявом психічної стійкості, що виявляється під час дії професійних стресових факторів і їх специфічність буде визначатися конкретним видом професійної діяльності.

Особлива увага в сучасних психологічних дослідженнях приділяється вивченню психологічних ресурсів особистості, які часто розглядаються як резерви, що дозволяють людині більш ефективно діяти і досягати успіху, долати стреси і справлятися з життєвими труднощами. Найважливішим в цьому сенсі напрямок досліджень полягає у вивченні того, як люди справляються з важки- 
ми життєвими подіями, за рахунок яких якостей і властивостей вони долають стрес.

3 метою вивчення особистісних ресурсів професійної стресостійкості студентів та фахівців різних соціономічних професій нами було проведено емпіричне дослідження, у якому взяло участь 198 студентів середніх та вищих навчальних закладів м. Чернівці та 214 фахівців, що працюють за різними соціономічними професіями; всього - 412 осіб. Студенти ЗВО склали 113 чоловік, ЗПО - 85 осіб. Вік досліджуваних - від 15 до 47 років $(\mathrm{M}=21,91 ; \sigma=5,69)$. Середній вік фахівців $(\mathrm{M}=24,43 ; \sigma=5,58)$ є істотно вищим, ніж студентів $(\mathrm{M}=19,19$; $\sigma=4,22)(\mathrm{p} \leq 0,001)$. Серед досліджуваних було 104 чоловіки та 308 жінок.

У дослідженнях було використано наступні методики: шкалу психологічного стресу PSM-25 (Lemyr-Tessier-Fillion), опитувальник втрат і придбань персональних ресурсів (Н. Водоп'янова, М. Штейн), методику самодіагностики типу поведінки в стресовій ситуації (В. Бойко), методику вивчення рівнів соціальної адаптації Холмса і Раге $[1 ; 3 ; 4]$.

Шкала психологічного стресу PSM-25 (адаптація Н. Є. Водоп'янової) призначена для виявлення рівня психічної напруги. В інтерпретації результатів чим більший показник психічної напруги, тим вищий є рівень психологічного стресу [1]. Опитувальник «Втрати і придбання персональних ресурсів», розроблений Н. Водоп'яновою і М. Штейн на основі ресурсної концепції психологічного стресу C. Хобфолла, згідно якої психологічний стрес і хвороби адаптації виникають при порушенні балансу між втратами і придбаннями персональних ресурсів. Автори методики вважають, що чим вищий є індекс ресурсності особи, тим більше збалансовані життєві розчарування та досягнення, вищий адаптаційний потенціал особистості і менша стресова вразливість [1]. Розроблена методика Т. Х. Холмса і Р. Х. Раге являє собою психометричну шкалу самооцінки актуального рівня стресу протягом останнього року і дозволила нам виявити рівень стресового навантаження в житті студентів та фахівців [3]. Опитувальник самодіагностики типу поведінки в стресовій ситуації (В. В. Бойко) дозволив нам визначити типи поведінки $\mathrm{A}, \mathrm{B}$ та A/B, тобто виявити, як студенти вузу та фахівці реагують на стрес та наскільки є схильними до впливу стресогенних факторів [4].

Порівняльний аналіз рівня психічної напруги студентів та фахівців.

У своєму дослідженні ми, передусім, прослідкували рівні прояву психічної напруги в житті сучасних студентів та фахівців соціономічних професій. Результати проведеного аналізу відображено в табл. 1 та на рис. 1.

Таблиия 1

Рівні психічної напруги студентів та фахівців $(\mathrm{N}=412)$

\begin{tabular}{|l|c|c|c|c|}
\hline \multirow{2}{*}{\multicolumn{1}{|c|}{ Рівні }} & \multicolumn{2}{|c|}{ Студенти } & \multicolumn{2}{c|}{ Фахівці } \\
\cline { 2 - 5 } & $\mathbf{N}$ & $\mathbf{N}$ & \% \\
\hline Низький & 160 & 74,8 & 109 & 55,1 \\
\hline Середній & 53 & 24,7 & 80 & 40,2 \\
\hline Високий & 1 & 0,5 & 9 & 4,7 \\
\hline
\end{tabular}


Наведені вище дані свідчать про те, що для сучасних студентів характерним $\epsilon$ низький $(74,8 \%)$ та середній $(24,7 \%)$ рівень психічної напруги. Серед фахівців 3 низьким рівнем є майже $55,1 \%$ досліджуваних та трохи менше половини - 3 середнім (40,2\%). Фахівців та студентів з високим рівнем психічної напруги є незначна кількість. Зазначені відмінності є статистично значущими: $\mathrm{t}(410)=-3,93, \mathrm{p} \leq 0,001 ; \mathrm{d}$ Cohena=0,39. Це означає, що рівень психічної напруги фахівців статистично вищий $(\mathrm{M}=95,95, \sigma=27,62)$, ніж у студентів $(\mathrm{M}=85,97$, $\sigma=23,62)$. Отримані дані узгоджуються 3 іншими нашими дослідженнями, а саме, що рівень психосоціального стресу фахівців є вищим, ніж у студентів [5].
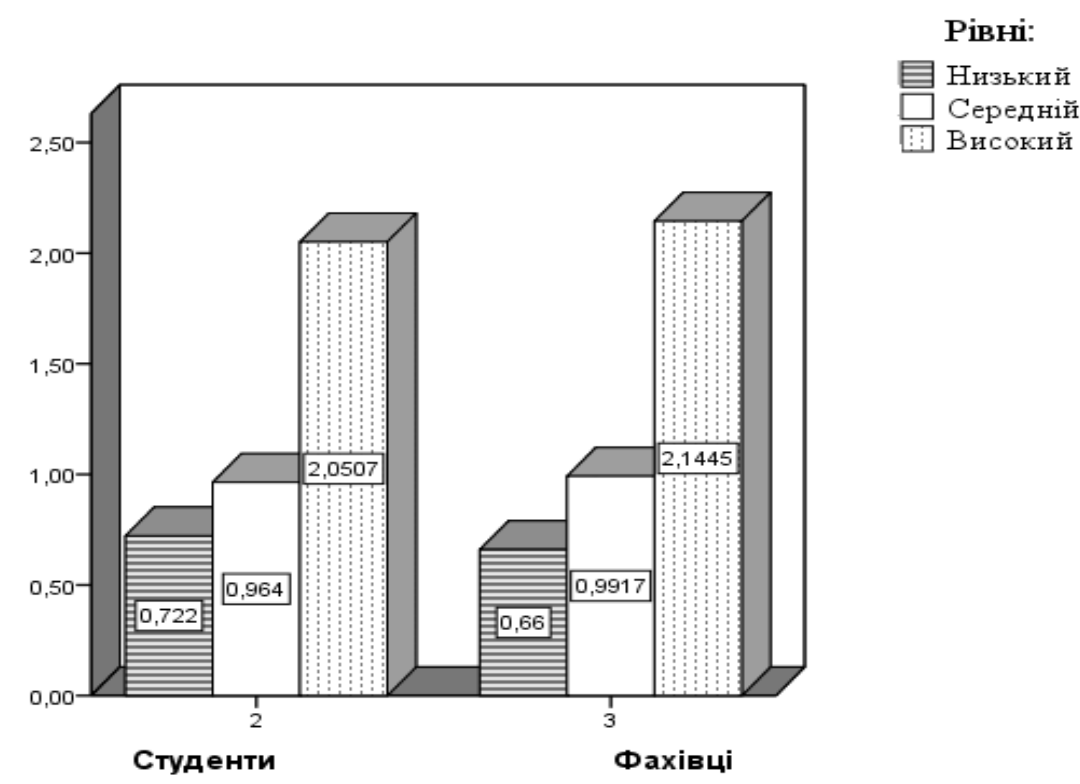

Рuc. 1. Розподіл досліджуваних за рівнями психічної напруги (М)

Порівняльний аналіз втрат та надбань персональних ресурсів студентів та фахівиів.

Наступним кроком нашого дослідження став порівняльний аналіз втрат та надбань персональних ресурсів студентів та фахівців. Ресурси - це те, що $є$ цінним для людини і допомагає адаптуватися до стресових ситуацій або долати стреси в житті. У контексті пропонованої методики ресурси розуміються як значні матеріальні засоби (матеріальний дохід, будинок, транспорт, одяг) i нематеріальні конструкти (бажання, цілі, система вірування, ідеї, переконання), зовнішні (соціальна підтримка, сім'я, друзі, робота, соціальний статус) і внутрішні - самоставлення і світогляд (самоповага, професійні вміння, оптимізм, самоконтроль, життєві цінності та ін.), стан душевного і фізичного благополуччя, вольові, емоційні та енергетичні характеристики, які необхідні (прямо чи опосередковано) для подолання реальних або передбачуваних життєвих стресів [1]. Відповідно до ресурсної концепції С. Хобфолла, психологічний стрес і ризик хвороб адаптації виникає при порушенні балансу між втратами і придбаннями персональних ресурсів. Результати проведеного аналізу представлено у табл. 2. 
Оцінки втрат і надбань персональних ресурсів студентів та фахівців ( $\mathrm{N}=412)$

\begin{tabular}{|l|c|c|c|c|c|c|}
\hline \multirow{2}{*}{ Показники } & \multicolumn{2}{|c|}{ Студенти } & \multicolumn{2}{c|}{ Фахівці } & \multirow{2}{*}{ t } & p \\
\cline { 2 - 5 } & $\mathbf{M}$ & $\boldsymbol{\sigma}$ & $\mathbf{M}$ & $\boldsymbol{\sigma}$ & $\mathbf{t}$ & 0,65 \\
\hline Надбання & 95,85 & 21,32 & 97,10 & 22,42 & $-0,45$ & 0,001 \\
\hline Втрати & 85,77 & 25,24 & 74,31 & 26,25 & 3,50 & \\
\hline
\end{tabular}

На основі аналізу критерію t-Student для незалежних груп виявлено значущі відмінності в оцінках втрат та надбань сучасними студентами та фахівцями. Спільним для досліджуваних груп є той факт, що вони значно вище оцінюють власні надбання, аніж втрати. Водночас, студенти істотно вище оцінюють свої втрати $(M=85,77, \sigma=25,24)$, ніж фахівці $(M=74,31, \sigma=26,25)$ $(\mathrm{p} \leq 0,001$; $\mathrm{d}$ Cohena=0,41). Разом 3 тим, фахівці значно вище оцінюють власні надбання (M=97,10, $\sigma=22,42)$, ніж студенти $(\mathrm{M}=95,85, \sigma=21,32)$, однак ці відмінності не істотні статистично ( $\mathrm{p} \geq 0,05)$.

Варто зазначити, що чим більше є придбаних внутрішніх ресурсів, тим вищою є здатність людини відновлюватися при втраті ресурсів зовнішніх, тим більша іï опірність середовищу, сильніша суб'єктність, воля, его-інтеграція, фокус контролю, самосвідомість і самоефективність, тобто іï стресостійкість при збереженні цілісності особистості.

Порівняльний аналіз рівня ресурсності студентів та фахівців.

Для розуміння проблеми ресурсів, треба також усвідомлювати, наскільки це динамічний процес, наскільки він знаходиться в русі. Не можна один раз накопичити ресурси, вони вимагають постійної взаємодії з середовищем, постійного розвитку та оновлення. Аналіз рівня ресурсності студентів та фахівців свідчить про їхні адаптаційні можливості. Результати аналізу представлено в табл. 3 та на рис. 2.

Таблиия 3

Рівні ресурсності студентів та фахівців (N=412)

\begin{tabular}{|l|c|c|c|c|}
\hline \multirow{2}{*}{\multicolumn{1}{|c|}{ Показники }} & \multicolumn{2}{|c|}{ Студенти } & \multicolumn{2}{c|}{ Фахівці } \\
\cline { 2 - 5 } & $\mathbf{N}$ & $\mathbf{\%}$ & $\mathbf{N}$ & \% \\
\hline Низький & 10 & 5 & 10 & 5 \\
\hline Середній & 53 & 27 & 96 & 45 \\
\hline Високий & 135 & 68 & 108 & 50 \\
\hline
\end{tabular}

Дані частотного аналізу показують, що для сучасних студентів та фахівців характерними є високий та середній рівень ресурсності, при цьому, серед студентів значно вищий відсоток осіб з високим його рівнем, порівняно з фахівцями. Слід наголосити, що чим вищий індекс ресурсності, тим більше збалансовані життєві розчарування і досягнення та вищий адаптаційний потенціал особистості, менша стресова вразливість. Однак, аналіз критерію t-Student свідчить про істотно вищий рівень ресурсності фахівців $(\mathrm{M}=1,52, \sigma=0,85)$, ніж студентів $(\mathrm{M}=1,27, \sigma=0,74): \mathrm{t}(410)=-2,61, \mathrm{~d}$ Cohena=0,37, $\mathrm{p} \leq 0,01$. Отримані дані також повністю узгоджуються з нашими дослідженнями рівнів стресостійкості студентів та фахівців: рівень стресостійкості фахівців є значно вищим, ніж у студентів [5]. 


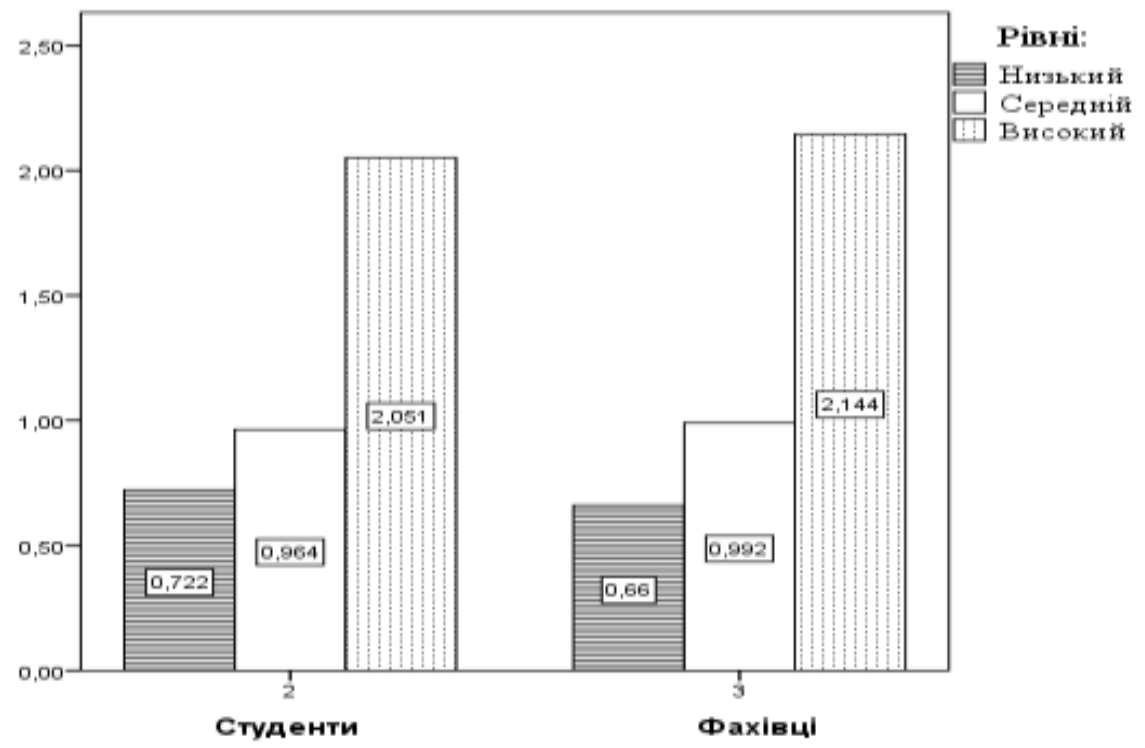

Рис. 2. Розподіл досліджуваних за рівнями ресурсності (М)

Типи поведінки студентів та фахівиів в стресовій ситуащії.

Опитувальник самодіагностики типу поведінки в стресовій ситуації, автором якого $\epsilon$ В. В. Бойко, дозволяє виявити три типи поведінки: А (стресогенний), В (стресостійкий) та проміжний тип А/В. Встановлено, що у так званому типі поведінки А певні риси характеру й погляди людини на життя стають першопричиною стресових симптомів. Водночас, у людей типу В рідше виникають психологічні проблеми в процесі взаємодії з іншими. Результати аналізу за методикою В. В. Бойко представлено у табл. 4.

Таблиия 4

Аналіз типів поведінки студентів та фахівців у стресовій ситуації ( $\mathrm{N}=412)$

\begin{tabular}{|c|c|c|c|c|c|c|}
\hline & $\begin{array}{l}\text { Типи } \\
\text { поведінки }\end{array}$ & $\%$ & M & $\sigma$ & $t$ & $\mathbf{p}$ \\
\hline \multirow{3}{*}{ Студенти } & Тип В & 22 & 63,72 & 10,45 & \multirow{6}{*}{$-2,83$} & \multirow{6}{*}{0,01} \\
\hline & Тип A/B & 57 & 87,01 & 6,16 & & \\
\hline & Тип А & 21 & 108,07 & 5,26 & & \\
\hline \multirow{3}{*}{ Фахівці } & Тип В & 22 & 67,25 & 7,64 & & \\
\hline & Тип A/B & 47 & 88,86 & 6,73 & & \\
\hline & Тип А & 31 & 112 & 9 & & \\
\hline
\end{tabular}

Домінуючим у поведінці студентів є проміжний тип А/B (57,6\%). Приблизно однакова кількість студентів - близько $21 \%$ - демонструє типи поведінки А (стресогенний) та В (стресостійкий). Порівняно з ними значно менший відсоток фахівців демонструє тип поведінки А/В (46,7\%) та більший відсоток тип А (30,7\%). Тип поведінки В приблизно з однаковою частотою виявляється як у студентів, так і фахівців (близько $2 \%$ ).

Варто наголосити, що стереотип поведінки А може спричинити також схильність студентів до різних захворювань. Водночас студенти, які належать до типу В чи A/B є такими ж активними, продуктивно працюють та досягають 
бажаного, як і люди типу А, однак без агресивності, нетерпіння, зберігаючи самопанування і здатність розслаблятися.

Виявлені відмінності є статистично значущими: $\mathrm{t}(410)=-2,83 ; \mathrm{p} \leq 0,01$; $\mathrm{d}$ Cohena=0,28. Це означає, що поведінка фахівців характеризується більшою стресогенністю, ніж поведінка студентів. Отримані дані узгоджуються з нашими дослідженнями рівнів психічної напруги, який у фахівців $є$ значно вищим, ніж у студентів.

Порівняльний аналіз рівнів сочіальної адаптащฺї студентів та фахівц̧ів протягом року.

Методику Т. Х. Холмса і Р. Х. Раге ми використали для вивчення самооцінки актуального рівня стресу протягом останнього року, що дозволило нам виявити рівень стресового навантаження в житті студентів та фахівців. Результати аналізу емпіричних даних представлено на рис. 3 та в табл. 5.

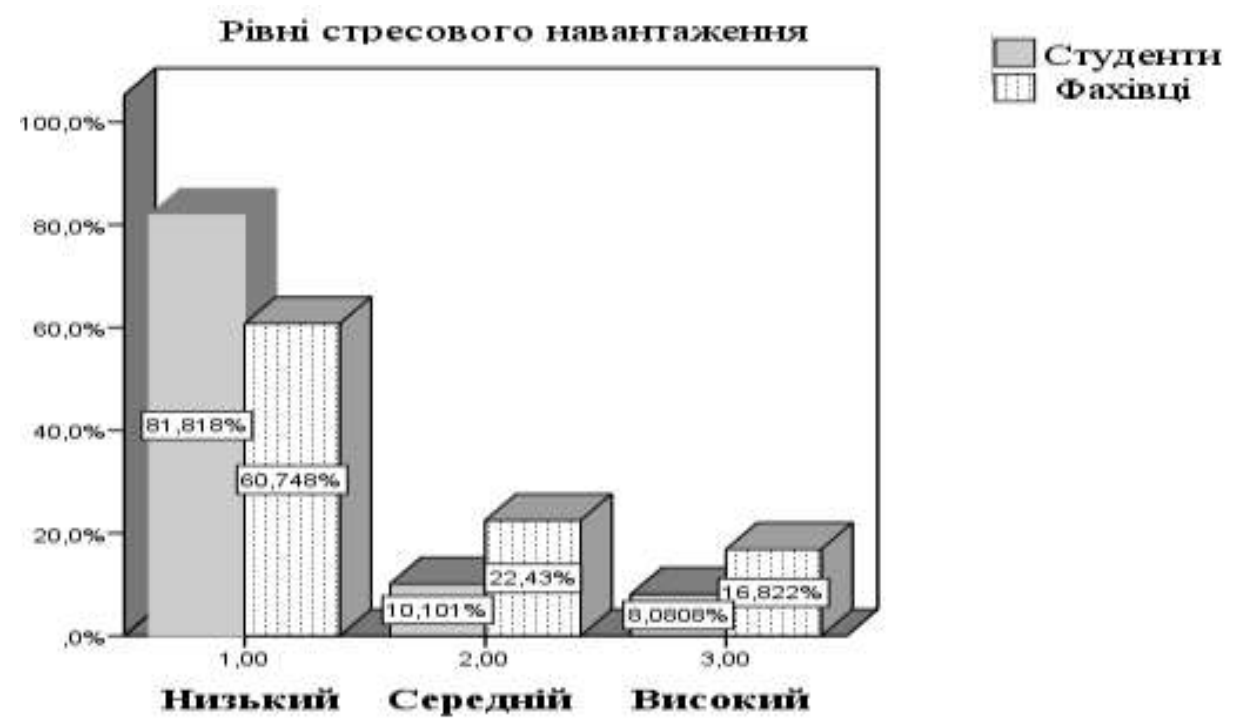

Рuc. 3. Розподіл досліджуваних за рівнями стресового навантаження (\%)

Наведені дані свідчать про вищий рівень стресового навантаження фахівців, порівняно зі студентами. Виявлені відмінності є статистично значущими: $\mathrm{t}(410)=-6,02 ; \mathrm{p}<0,001 ; \mathrm{d}$ Cohena=0,59.

Рівень стресового навантаження студентів та фахівців ( $\mathbf{N}=412)$

\begin{tabular}{|c|c|c|c|c|}
\hline \multicolumn{2}{|c|}{ Показники } & Низький & Середній & Високий \\
\hline \multirow{3}{*}{ Студенти } & $\mathrm{M}$ & 96,65 & 243,20 & 349,38 \\
\cline { 2 - 5 } & $\sigma$ & 57,85 & 23,26 & 28,34 \\
\hline \multirow{2}{*}{ Фахівці } & $\mathrm{M}$ & 120,45 & 247,38 & 375,50 \\
\cline { 2 - 5 } & $\sigma$ & 48,77 & 27,27 & 48,96 \\
\hline
\end{tabular}

Отримані дані узгоджуються з дослідженнями рівнів психічної напруги, який у фахівців є значно вищим, ніж у студентів.

Висновки і перспективи подальших розвідок у даному напрямку. На основі узагальнення викладеного вище можна зробити наступні висновки: 
Для сучасних українських студентів закладів вищої та середньої освіти характерним $є$ низький та середній рівень психічної напруги, тоді як поведінка фахівців характеризується більшою стресогенністю. Однак саме фахівцям властивий високий рівень ресурсності: вони більш сконцентровані на своїх досягнення і надбаннях та значно менш - на втратах.

Таким чином, адаптаційні можливості людини і стійкість до стресогенних життєвих обставин обумовлені типом особистості, в якій провідну роль відіграють особистісні (соціально-психологічні) ресурси, під впливом яких виробляється індивідуально-специфічне ставлення до стресової ситуації.

Перспективними напрямками подальших досліджень вважаємо дослідження психологічних особливостей прояву професійної стресостійкості на різних вікових етапах професійного розвитку фахівця, зокрема, у відповідності до шляху досягнення фахівцем професіоналізму.

1. Водопьянова Н. Е. Психодиагностика стресса. Санкт-Петербург : Питер, 2009. 336 с.

2. Дубчак Г. М. Розуміння професійної стресостійкості у психологічній літературі. Науковий вісник Чернівецького університету : зб. наук. пр. Чернівці : Чернівецький нац. ун-т, 2014. Вип. 649 : Педагогіка та психологія. С. 39-47.

3. Практическая психодиагностика. Методики и тесты / ред. Д. Я. Райгородский. Самара : Издательский Дом «БАХРАХ-М», 2000. 672 с.

4. Титаренко Т. М., Лєпіхова Л. А., Кляпець О. Я. Формування в молоді настанов на здоровий спосіб життя : методичні рекомендації. Київ : Міленіум, 2006. 124 с.

5. Dubchak H. Characteristics of tolerance to stress of future specialists with socionomy occupations. Social Welfare : Interdisciplinary approach. 2015. Vol. 2. № 5. P. 8-18. 